\title{
Research on Cultivation Platform Construction of Financial IT Outsourcing Talents
}

\author{
Zhao Jun \\ Wuhan Textile University \\ Wuhan, China \\ E-mail: 282762010@qq.com
}

\begin{abstract}
With the increasingly fierce competition in the financial market and the increasing complexity of financial instruments and business, the financial industry becomes more and more dependent on information technology to control costs, improve services, as well as promote competitiveness, nevertheless, a lack of financial IT outsourcing talents in China has become a problem gaining increasing prominence. This paper, based on the analysis of current situation of demand for financial IT outsourcing talents and the future development prospects, dissects and summarizes current problems of the cultivation pattern of financial IT outsourcing talents, and also, gives such cultivation certain positions, according to which, different ways of talents cultivation platform construction are suggested accordingly and respectively.
\end{abstract}

KeyWords-Financial services outsourcing; financial IT outsourcing; talents cultivation pattern; talents cultivation platform

\section{I.INTRODUCTION}

Financial service outsourcing is a major sector of services outsourcing. By definition, financial service outsourcing, according to Financial Service Outsourcing, a guideline in supervision issued by Basel Committee on Banking Supervision in February, 2005, refers to that financial institutes, on the basis of continuous operation, take advantage of contract-issuing party (affiliated entities inside or entities outside the financial institutions) to carry out business activities that would normally have been undertaken by those institutions themselves. Financial service outsourcing, in essence, is that financial firms outsource non-core financial back-office businesses to professional financial service outsourcing companies, while focusing on those core businesses, in order to reduce costs, improve efficiency and optimize the operation process, thus enhancing the firms' core competitiveness. Financial service outsourcing mainly consists of three parts, financial IT outsourcing, financial operation process outsourcing and financial knowledge process outsourcing.

Financial service outsourcing originates in the 1970s and burgeons in the 1990s. At present, financial service outsourcing has extended to financial institutions like banks, securities, investments, insurances, etc. in different sizes and levels. Among all industries, the global outsourcing scale of financial industry is just smaller than that of manufacturing industry. The report Focus on the Giant (2010) released by Deloitte \& Touche indicates that large financial firms are more likely to conduct/carry out offshore business than small companies and that more and more companies are planning or establishing offshore business institutions. Global outsourcing businesses are contracted out mostly by developed countries, among which America accounts for 2/3, EU and Japan nudge 1/3, while other countries share an extremely tiny proportion. By contrast, developing countries are primary recipients of those financial outsourcing businesses of which Asia undertakes the largest amount with a percentage of $45 \%$.

Financial IT outsourcing means that financial institutions entrust part or all of the information technology services to professional IT service providers, including system operation service, system application service and fundamental technology service. According to a 2011 research report from CCW Research (China Computer World Research), the market share of Chinese financial IT outsourcing service market in 2010 was 7.457 billion RMB. With a year-on-year growth rate of $21.03 \%$, the compounded growth rate of the Chinese financial IT outsourcing market was projected to be $22.91 \%$ for the years 2011-2014.

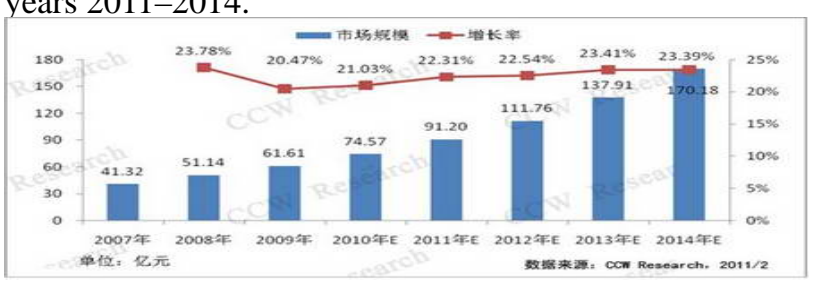

\section{THE URGENCY OF CULTIVATING FINANCIAL IT OUTSOURCING TALENTS}

Chen Wenjing, former vice president of Academy of international Trade and Economic Cooperation, MOFCOM once said that compared with India, the pace-setter in global service outsourcing, a shortage of practitioners has become a haunting impediment to the sustainable development of the sector. Quite a lot of services outsourcing companies are super desperate to expand the business scale, but the predicament of talents scarcity hinders this movement. Every year in China the number of talents shortage in service outsourcing is up to 200,000 and in financial outsourcing sector this number is around 60,000 . However, the number of graduating students of related majors every year is less than 1,000 .

After the financial crisis in 2008, financial service outsourcing in China has experienced rapid development, but the problem of talents shortage has been increasingly prominent and become a bottleneck impeding in-depth development of Chinese financial service outsourcing. 
Since in China no effective cultivation system of financial service outsourcing talents has been established plus governments and related associations haven't formulated an effective long-run plan of talents cultivation, it seems particularly urgent, under such circumstances, to set up a market-oriented cultivation platform and system of financial service outsourcing talents.

\section{ANALYSIS OF DEMAND FOR FINANCIAL SERVICE OUTSOURCING TALENTS}

There are five major demands from the financial service outsourcing industry for talents in this field. The first is from offshore operation centers in China of international financial institutions, such as HSBC, Citibank, Standard Chartered Bank, etc. The second is from service centers in China of large multinational service outsourcing providers, like BearingPoint, Accenture, etc. of which a large part of the business are finance-related. The third is from domestic financial institutions as contract-issuing party. These institutions also have a demand for management talents in financial service outsourcing who can accommodate the demand side; meanwhile, many domestic financial institutions are also establishing background service centers. The fourth is from domestic service outsourcing providers, Pactera, iSoftStone, Insigma, just to name a few, as well as professional financial service outsourcing providers like China Data Group (CDG), Global Data Solutions (GDS) and so on. The fifth is from current industrial parks of financial service outsourcing in various areas. The planning, operation and management of these industrial parks also call for financial service outsourcing talents.

The demand for financial IT outsourcing talents mainly comes from IT companies, background service centers of domestic financial institutions, IT outsourcing providers, capable of undertaking IT outsourcing businesses of large commercial banks. At present, in Chinese financial sector, there is a tendency of accelerating separation between core business and non-core business, between foreground business and background business, and between standard process business and non-standard process business. In addition, financial institutions cry out for the likes of financial background service centers, IT outsourcing providers and professional financial service outsourcing providers to bear the pressure from non-core businesses. Therefore, the demand for financial IT outsourcing talents is ballooning.

\section{PLATFORM CONSTRUCTION OF CULTIVATION OF FINANCIAL IT OUTSOURCING TALENTS IN DIFFERENT LEVELS}

A. Problems of Existing Cultivation Pattern of Financial IT Outsourcing Talents in China and Positioning of Talents Cultivation

- Problems of Existing Cultivation Pattern of Financial IT Outsourcing Talents in China

According to Research Report on Service Outsourcing
Development in China compiled by COI, the most authoritative service outsourcing research center in China, based on the practices of financial service outsourcing talents cultivation in different areas, national demonstration cities in service outsourcing typically feature in service outsourcing talents cultivation as follows: Talents cultivation of Shanghai, aiming at cultivating middle and high level talents, is characterized by overseas introduction and domestic cultivation of leading elites in service outsourcing, laying a particular emphasis on cultivation of middle and high level talents; Wuxi, leaded by the government, has set up a training alliance around the city. It features large amounts of talents cultivation bodies and institutions, among which professional parks are dominant; Chengdu, however, lays stress on cooperation between service outsourcing companies and colleges and universities. Its main characteristic is the adoption of dual-supervisor mechanism in training cooperation, both sides jointly arranging training courses and giving priority to cultivating middle-level talents in service outsourcing.

In view of current cultivation pattern of financial IT outsourcing talents in China, the major problems are as follows:

(1) "Dislocation between production and need" in education mode of colleges and universities

In China, financial IT outsourcing is still an emerging industry, of which schools, teachers and students don't have adequate recognition and understanding. Since the "Thousand, Hundred, Ten" project initiated by Ministry of Commerce, a lot of colleges and universities have just regarded traditional school of software engineering as one of service outsourcing in form, while actually there was no thoroughgoing reform of the curriculum system. Colleges and universities have no acquaintance with the capacity of students required for financial IT outsourcing market. Moreover, since a majority of teachers have no relevant working experience, it's difficult to produce graduates fitting the bill. As a matter of fact, it is compound talents, not only knowing well about software development, but also possessing knowledge of finance and accounting that are in demand by financial IT outsourcing market. Since only a few colleges and universities have established the major of financial information service and most of them are in their infancy, a systematic cultivation system of financial IT outsourcing talents has not yet come into being.

(2) Uneven teaching quality in training and certification agencies

Currently, although the training mode of those training and certification agencies attaches importance to pertinence and practicability of the courses, due to their profit-making purpose, the teachers are uneven in teaching quality. Teachers with working experience of financial IT outsourcing are often part-time, whose training time and content can not be effectively controlled, thus to a large degree negatively affecting the training result and students having no competence as certified.

(3) Excessively high training costs of the training 
mode in financial IT outsourcing companies

Although the training mode in financial IT outsourcing companies is targeted and effective, many companies undertaking the financial IT outsourcing businesses can't afford the high training costs. Besides, if employees resign after being trained, the companies would suffer huge losses, which becomes a factor blocking the development of the training mode in financial IT outsourcing companies.

Positioning of China's Financial IT Outsourcing Talents Cultivation

Highly qualified and compound outsourcing talents are the prerequisite for financial IT outsourcing development. According to the classification of financial IT talents, technical personnel lay the foundation of outsourcing companies. They are the indeed implementer of financial IT outsourcing businesses. The cultivation of this type of professionals shall be orientated at a good command of computeracy such as database, network security, operating system, etc., plus basic financial knowledge from the technical perspective, strong teamwork awareness and cooperation competence, as well as good time management capacity. For those middle-level project managers of financial IT outsourcing projects, besides the basic knowledge and competence of financial IT outsourcing talents, they should also be trained with project management knowledge. Their ultimate competence should include excellent team communication skills, good team operation management and implementation management capacity, effective personnel management capacity, strong analysis and problem-solving capacity, the competence to identify the efficiency variation of team members, as well as the competence to maximize the financial IT outsourcing business opportunity. When it comes to the senior personnel or top talents, in addition to the knowledge and competence of middle-level project managers, they should also have a good command of language, culture and law system of the contract-issuing party, possess the competence to do strategic forecast, initiate innovation, with which they can develop various kinds of peripheral and value-added service based on the further development needs of financial institutions in order to raise the value of those clients in which it invests.

\section{B. Setting up a Cultivation Platform to Meet the Demands} of Companies for Different Levels of Financial IT Outsourcing Talents

In Response to the Cultivation Positioning of Financial IT Outsourcing Talents, it's suggested to set up an alliance of colleges and universities and cooperate with information technology outsourcing providers, professional financial service outsourcing providers as well as backstage service centers of financial institutions to establish a teaching base and fieldwork base.

Financial IT outsourcing not only requires the computer knowledge of database, network security, operation system, etc., but also need financial service outsourcing knowledge. Right now, most of universities in
China can't meet its overall professional demands. By contrast, many polytechnic colleges have advantages in several aspects such as computer application technology and information security. These colleges can make full use of their local economy to set up an alliance of colleges and universities. In the meantime, they can cooperate with information technology outsourcing providers, professional financial service outsourcing providers as well as backstage service centers of financial institutions to establish a visual institute and maintain long-term stable partnership.

The alliance of universities and colleges can do a joint research with companies and cooperate with each other to formulate the training objectives, teaching programs, teaching contents as well as training methods for financial IT outsourcing technical talents. Of course, this also requires the Ministry of Education to expand the autonomy of universities in course arrangement.

The curriculum system for financial IT outsourcing technical talents shall contain not only compulsory curriculum for computer majors, for example, the $\mathrm{C}$ Programming Language, Linux, data structure, database, operation system, computer networks etc. but also special programs like financial software development, financial management service, business English, as well as fieldwork training courses such as model financial system, financial system practices and simulating operation, application and operation of relative accounting principles, processing skills of Accounts receivable and payable and General Ledger, etc. In fieldwork training courses, financial IT outsourcing companies can take advantages of the various businesses they undertake, set up several project developing teams on campus, delegate the project manager or teachers to direct students in their development process. In the one hand, this method can cultivate students' operational and practical ability, give them an opportunity to experience the real working environment of financial IT outsourcing industry, make them familiar with business process of financial system, have a rough understanding of the characteristic and processing method of financial data as well as how IT technology serves financial outsourcing industry. On the other hand, it also provides conveniences for companies in terms of talents recruitment and project development.

According to the Cultivation Positioning of Middle-Level Project Managers for Financial IT Outsourcing Industry, it is suggested to Establish a Cultivation Platform both Containing Non-academic Education Programs and Enterprise Training Programs. The cultivation programs of middle-level project managers for financial IT outsourcing industry usually choose those who have worked in the enterprise for some time, and have revealed their administrative talent in the routine work. Generally, these technical talents all have rich experience and technical foundations; but are lack of project management knowledge. Therefore, universities and financial IT outsourcing companies should cooperate with each 
other to establish a cultivation platform both containing non-academic education programs and enterprise training programs, taking advantage of the educational resources and faculty resources of universities to provide those technical talents of huge development potential with training courses about project management knowledge and its application, project performance assessment and management practice, project management practices as well as team building and management. In addition, universities also provide MBA training for those who wish to proceed further education to transform themselves into excellent managers with systematical management theory and knowledge.

- Aiming at the Cultivation of Senior Personnel or Top Talents, it is suggested to Establish International Cooperation.

It is difficult to cultivate senior personnel or top talents through present mode from universities and training agencies. Thus, the cultivation of senior personnel or top talents mainly relies on practices within the enterprises and experience accumulation, as well as overseas training.

Senior personnel or top talents of financial IT outsourcing industry are required to have a good command of the language, culture and law system of the contract-issuing party, possess the competence to do strategic forecast, initiate innovation, with which they can develop various kinds of peripheral and value-added service based on the further development needs of financial institutions in order to raise the value of those clients in which it invests. According to the global finance offshore outsourcing service industry, the contract-issuing markets are mainly in some areas and regions like North America, Western Europe and Japan. Sending these middle-level financial IT outsourcing management personnel with rich project management experience to study aboard and do practices in contract-issuing enterprises in Europe, American and Japan can not only give domestic financial IT outsourcing companies a clear understanding of the demand feature and operation pattern of contract-issuing party, making them familiar with the language and life style of their potential clients, but also enhance the management experience of those financial IT outsourcing project managers. Domestic financial IT outsourcing companies can set up a long-term cooperative mechanism with those contract-issuing companies in Europe, America and Japan, build a collaboration system to cultivate senior personnel, which also requires government to give some extent of policy and financial support.

\section{REFERENCES}

[1]Zhang Qiaoyun, Several Problems in the Financial Services Outsourcing and Financial Outsourcing Personnel Training [J]. Gansu Finance, 2010 (10). [2]Yang Yi, Fu Qiao Ling, Li Han., A comparative study of university training model of financial services outsourcing talents [J]. Beijing Education, 2012 (05). [3]Li Yong, Xu Rong, Training
System Construction on Financial Service Outsourcing Talent. [J]. Vocational Education Research, 2012 (09).

[4]Wang Jian. Status and Prospects of Financial IT Outsourcing [J]. Chinese credit cards, 2007 (24) [5]Rui-Lin Liu. Research on Training Experimental Teaching System of Financial Services Outsourcing Talent [J]. Computer Education, 2009 (15). 